\title{
Assessment of Radioactivity Contents and Radiological Effects of Marble, Granite, and Ceramic Used in Alexandria City, Egypt
}

\author{
N. M. Ibrahim*, I. H. Saleh, and Z. F. Ghatass \\ Department of Environmental Studies, Institute of Graduate Studies and Research, Alexandria University
}

\begin{tabular}{|c|c|}
\hline ARTICLE INFO & ABSTRACT \\
\hline Article history: & \multirow{8}{*}{ 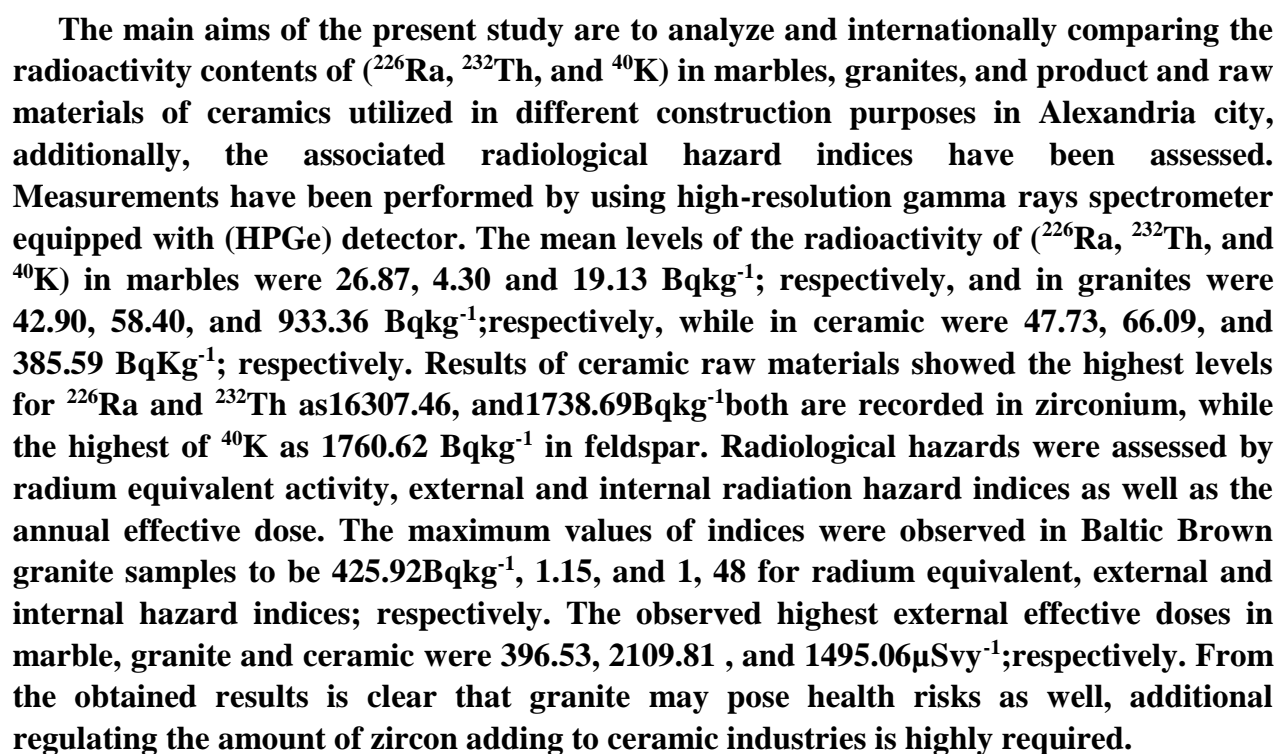 } \\
\hline Received: $30^{\text {th }}$ Jan. 2021 & \\
\hline Accepted: $5^{\text {th }}$ Apr. 2021 & \\
\hline Keywords: & \\
\hline Radiological Hazards; & \\
\hline Radioactivity; & \\
\hline Marble; Granite; & \\
\hline Ceramic. & \\
\hline
\end{tabular}

\section{INTRODUCTION}

Natural radioactive materials that exist in building materials $\left({ }^{226} \mathrm{Ra},{ }^{232} \mathrm{Th}\right.$, and $\left.{ }^{40} \mathrm{~K}\right)$ contribute to the external and internal radiation exposures for the general public. Externally, due to gamma radiation emitted from solid radionuclides in these materials while internally due to ${ }^{222} \mathrm{Rn}$ gas and its daughters $\left({ }^{218} \mathrm{~Pb},{ }^{214} \mathrm{~Pb}\right.$, and ${ }^{214} \mathrm{Bi}$ ) that released into the atmospheric and then inhaled reaching the lung [1].

Natural rocks are widely used for many administrative and government buildings, homes, and flats. Marble and granite are used for entrance halls, living rooms, cooking work places and bathrooms. Due to its aesthetic features marbles tiles are highly used for interior flooring, while granite for exterior cladding and in the funerary art [2].

It is well known that, thorium and uranium concentrations in the minerals are highly associated with the geochemical and mineralogical properties of source[3].
Marbles are mainly formed from metamorphic rocks which originated from calcareous subjected to high temperatures and pressures. Therefore, they are concentrated in the regions of calcareous matrix-rocks and volcanic activities and well known for their high natural radioactivity content, depending on the geological conditions and geographical sources [4].The minerals that characterizing marble nature are Quartz, Garnet, Biotite, Microline, Muscovite, Tremolite, Actinolite, Chert, Fosterite, and Talc. In addition to that it contains trace impurities such as $\mathrm{SiO}_{2}, \mathrm{Fe}_{2} \mathrm{O}_{3}, 2 \mathrm{Fe}_{2} \mathrm{O}_{3}$, and $\mathrm{H}_{2} \mathrm{O}$, Limonite, Manganese, $\mathrm{Al}_{2} \mathrm{O}_{3} \cdot \mathrm{FeS}_{2}$ [5].

Granite igneous rocks are extended areas in mountain belts and continental shelves. They are formed of huge batholiths that distributed in wide areas. They are related closely with quartz, gabbro, monzonite, and diorite. Granites were formed mainly from magmatic separation of basalt as well there indications that was of metamorphic origin. They are characterized by scratch resisting and durability. Their hardness lends them for mechanically polished to a high gloss finish [6-8]. 
Granite components are mainly quartz, potassium and sodium, mica, and components from silica, aluminum, potassium oxide, soda, and smaller quantities of iron, magnesia, and Titania. Granites contain high levels of uranium and thorium compared to the minerals existing in the crust of the Earth [8].

Ceramic is also considered as possible sources for indoor radiation exposure due to its content of uranium and thorium salts in its raw materials. Ceramic is manufactured from raw materials such as clays, quartz and feldspars [9]. These raw materials are often classified according to their purposes. For economic consideration, there is an increasing need for uses more suitable low cost in applications at low temperature [10].

This study aimed to evaluate the levels of natural radionuclides and comparing them with those in different countries of the world; furthermore, to assess the radiological risk for marble, granite and ceramic manufactured and marketed in Alexandria, Egypt.

\section{MATERIALS AND METHODS}

\section{Sampling}

This study includes 17 types of marble, 12 types of granite and 16 types of ceramic that were picked up from Alexandria local workshops, also ceramic plates and ceramic raw materials were collected from its manufacturing sites. The studied samples were collected from two sites (El-Dreesa and Kourshed) in Alexandria city, as shown in Figure (1). The workshops receive

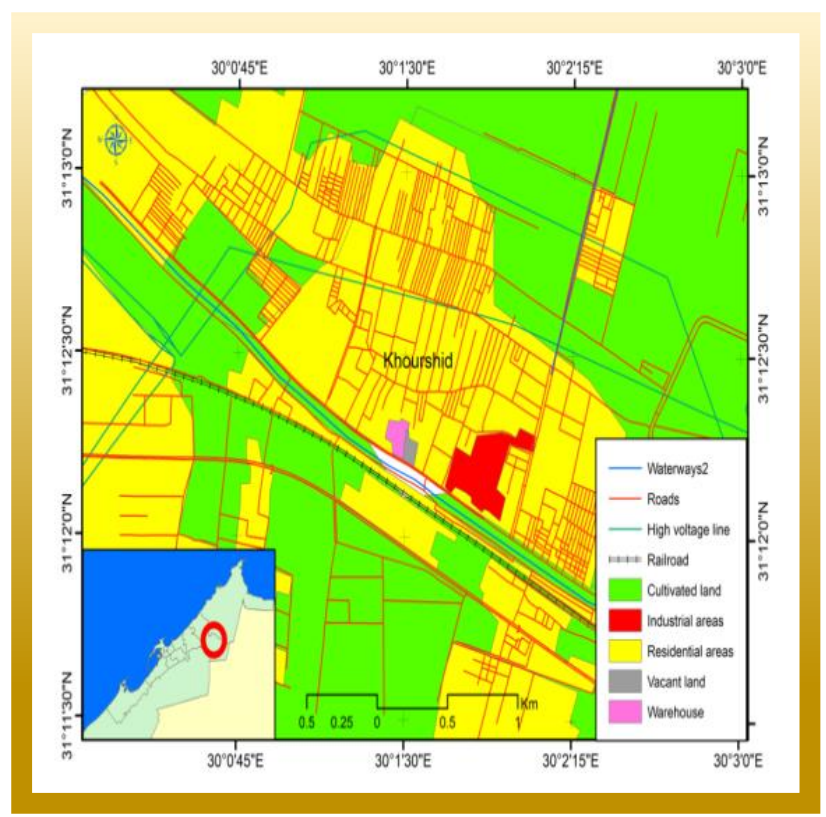

large masses of granite and marble that are cut into strips and burnished for using in construction process. All samples were prepared includes cleaning, drying, and grinding then weighting and packing in one liter special radiation counting container (Marinelli beaker)then the radioactivity were measured by using gamma rays spectrometer equipped with (HPGe) detector.

\section{Radioactivity Measurements}

The detection system consists of Closed-End (HPGe) gamma detector with sensitive volume of $108 \mathrm{~cm}^{3}$, and energy range of $60 \mathrm{KeV}$ to $2000 \mathrm{KeV}$. The relative efficiency is $24.5 \%$ and resolution is $1.95 \mathrm{keV}$ at $1.33 \mathrm{MeV}$. The detector shield is made of lead of $0.1 \mathrm{~mm}$ thickness with an internal cover made of copper.[11-13].

The energy calibration was carried out by using gamma radiation standard sources $\left({ }^{137} \mathrm{Cs},{ }^{60} \mathrm{Co},{ }^{57} \mathrm{Co}\right.$ and $\left.{ }^{241} \mathrm{Am}\right)$. The full-energy photopeak efficiency calibrations for solid samples (granite and marble and ceramic), were carried out for different densities and geometrical shapes ${ }^{[14]}$.For disc shape by using standard sources $\left({ }^{57} \mathrm{Co},{ }^{60} \mathrm{Co},{ }^{134} \mathrm{Cs},{ }^{137} \mathrm{Cs}\right.$ and $\left.{ }^{54} \mathrm{Mn}\right)$ and for bulk shape by using ${ }^{152}$ Eupacked in Marinelli of one litter volume (M-Solid). Reference martials that are necessary for verifying the calibrations were supplied via MAPEP (Mixed Analyte Performance Evaluation Program) organized by Radiological and Environmental Science Laboratory, Radiation Measurement Cross Calibration Program, The U. S. Department of Energy. The efficiency calibrations are shown as Figure (2).

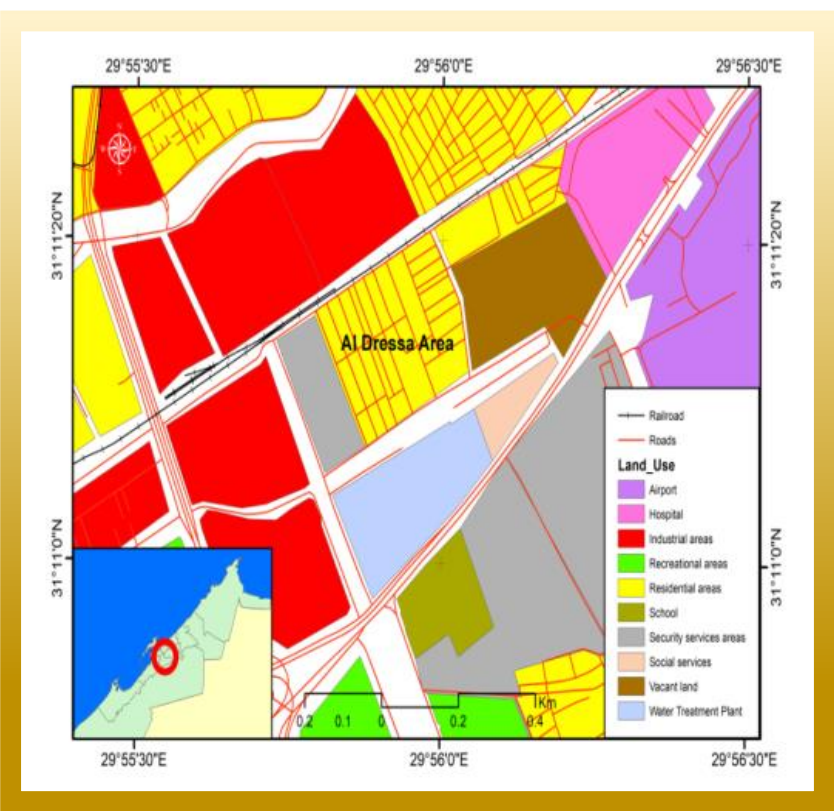

Fig. (1): Land uses of studies areas El-Dreesa and kourshed sites 


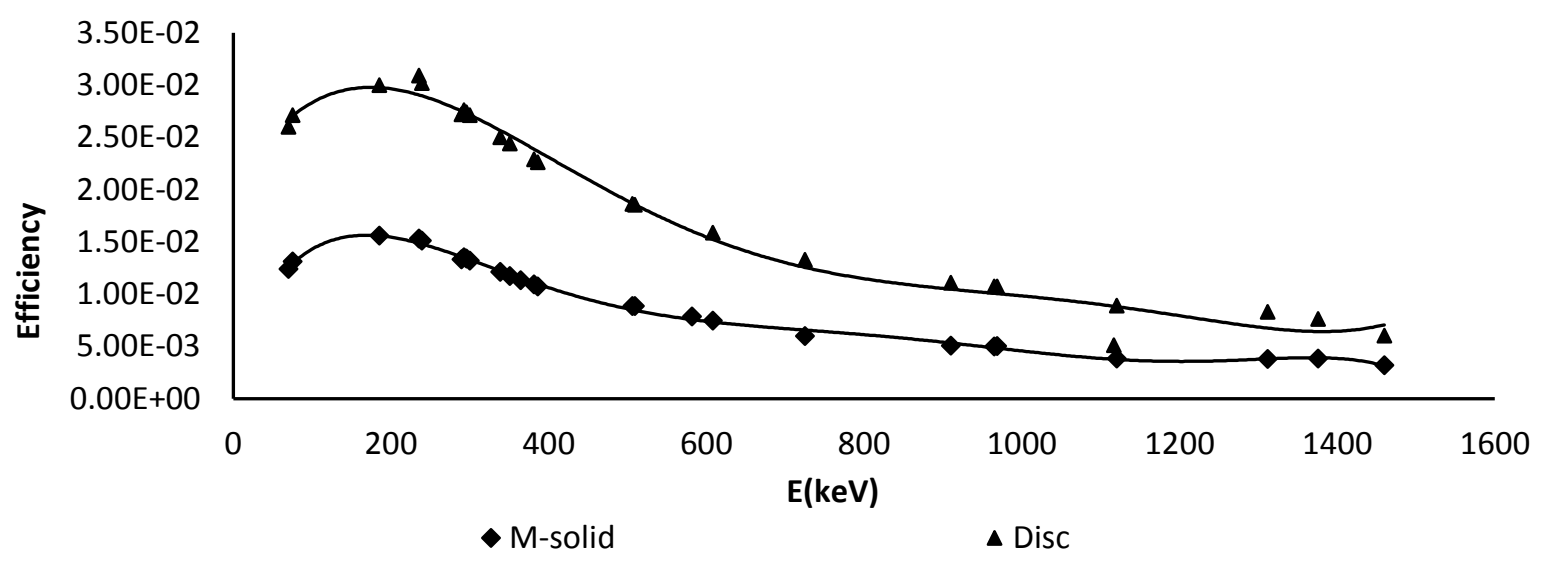

Fig. (2): The efficiency calibration curves with different geometry of standard source

\section{Determination of minimum detectable activity determination}

The minimum detectable activity (MDA) for radionuclides was calculated by the following equation(1):

$$
\text { MDA }=\frac{\text { LD }}{\text { T X Eff(E)X P } \gamma(E) X M}
$$

Where; $\mathrm{T}$ is the counting time, Eff (E) is absolute full gamma energy peak efficiency at energy $\mathrm{E}$ and $\mathrm{P} \gamma(\mathrm{E})$ is probability per decay. LD is the detection limit that obtained from equation (2):

$$
\mathbf{L}_{\mathbf{D}}=\mathbf{L}_{\mathbf{C}}+\mathbf{K} \mathbf{\sigma}_{\mathbf{D}}
$$

Where $\mathrm{L}_{\mathrm{C}}$ is the level below which no signal can be detected, $\sigma_{\mathrm{D}}$ is the standard deviation and $\mathrm{K}$ is the error probability [15].Table (1) lists MDA values calculated based on the used counting conditions.

Table (1): The MDA values for the determined radionuclide $(\mathrm{Bq} / \mathrm{kg})$ using detection time $160000 \mathrm{~s}$ and mass of $1 \mathrm{~kg}$ with confidence levels $\alpha=5 \%, \beta=5 \%$

\begin{tabular}{cc}
\hline Radionuclides & MDA(Bq/kg) \\
\hline${ }^{22} \mathrm{Ra}$ & 0.01 \\
${ }^{214} \mathrm{~Pb}$ & 0.02 \\
${ }^{214} \mathrm{Bi}$ & 0.34 \\
${ }^{228} \mathrm{Ra}$ & 0.5 \\
${ }^{212} \mathrm{~Pb}$ & 0.13 \\
${ }^{40} \mathrm{~K}$ & 0.01 \\
\hline
\end{tabular}

\section{Radiological Assessments of Radiation}

Many radiological assessments are performed to evaluate compliance of the radiation exposures levels with the recommended guidance levels that are concerned with protection of public health and the environment.

\section{The Radium Equivalent Activity}

The radium equivalent activity, $\underline{\boldsymbol{R} \boldsymbol{a}_{\boldsymbol{e q}},}$ index was introduced by Beretka and Mathew; it was defined as a single quantity that represents the combined specific activities of $\left({ }^{238} \mathrm{U},{ }^{232} \mathrm{Th}\right.$ and $\left.{ }^{40} \mathrm{~K}\right)$. It was developed as an indicator to assess external exposure to public [16].

It is deduced equation (3):

$$
\mathrm{Ra}_{\mathrm{eq}}=\mathrm{A}_{\mathrm{Ra}}+\mathbf{1 . 4 3 A}_{\mathrm{Th}}+\mathbf{0 . 0 7 7 A _ { \mathrm { k } }}
$$

Where, $\mathrm{A}$ is the specific activities in $\mathrm{Bq} \mathrm{Kg}^{-1}$ of ${ }^{226} \mathrm{Ra}$, ${ }^{232} \mathrm{Th}$ and ${ }^{40} \mathrm{~K}$,is based on the fact 370,259 , and 4810 ; respectively, that produced the same gamma dose rate and assuming radioactive equilibrium to be established in both ${ }^{238} \mathrm{U}$ series and ${ }^{232} \mathrm{Th}$ series $[17,18]$.

\section{Hazard Indices}

External radiation exposure due to ${ }^{226} \mathrm{Ra},{ }^{232} \mathrm{Th}$ and ${ }^{40} \mathrm{~K}$ is external assessed by external hazard index, $\mathrm{H}_{\text {ex }}$. Its level is calculated by equation (4) [19, 20].

$$
H_{\text {ex }}=A_{\mathrm{Ra}} / 370+A_{T h} / 259+A_{K} / 4810
$$

For the safe use of a stone $\mathrm{H}_{\mathrm{ex}}$ should be less than unity.

The internal exposure to radon and its daughter products is quantified by the internal hazard index, $\mathrm{H}_{\mathrm{in}}$, which is given by the equation (5).

$$
H_{\text {in }}=A_{R a} / 185+A_{T h} / 259+A_{K} / 4810
$$

Where $A_{R a}, A_{T h}$ and $A_{K}$ are defied in equation (3). For the safe use as building materials $\mathrm{H}_{\text {in }}$ should be less than unity[21, 22]. 


\section{Absorbed Dose Rate and the annual effective dose}

The gamma absorbed dose rates, $\mathrm{D}$, in (nGy/h) in outdoor and indoor air are given by:

$$
\begin{aligned}
& D_{\text {out }}=0.4299 A_{\mathrm{Ra}}+0.666 \mathrm{~A}_{\mathrm{Th}}+0.042 \mathrm{~A}_{\mathrm{K}} \\
& D_{\text {in }}=0.92 \mathrm{~A}_{\mathrm{Ra}}+1.1 \mathrm{~A}_{\mathrm{Th}}+0.081 \mathrm{~A}_{\mathrm{K}}
\end{aligned}
$$

Where: $A_{R a}, A_{T h}$, and $A_{K}$ as they are given in equation (3). For the safe use of a stone D must be lower than the recommended value $55 \mathrm{nGy} / \mathrm{h}$ [23].

The annual effective doses (AEDs) in outdoor and in indoor as were calculated by using equations 8 and 9[24];

$\left.\operatorname{AED}_{\text {outdoor }}(\mathrm{mSv})=D_{\text {out }}\left(\mathrm{nGyh}^{-1}\right) \times \mathbf{X 7 6 0}^{\mathrm{h}} / \mathrm{y}\right) \mathrm{X0.7}(\mathrm{Sv} / \mathrm{Gy}) \mathbf{1 0}^{-6} \mathrm{X0.2}$

$\mathrm{AED}_{\text {indoor }}(\mathrm{mSv})_{=} \mathrm{D}_{\text {in }}\left(\mathrm{nGyh}^{-1}\right) \times \mathbf{8 7 6 0}(\mathrm{h} / \mathrm{y}) \mathrm{X0.7}(\mathrm{Sv} / \mathrm{Gy}) \mathbf{1 0}^{-6} \mathrm{X} 0.8$

According to UNSCEAR $1993^{[25]}, 0.7 \mathrm{SvGy}^{-1}$ is the conversion coefficient from absorbed dose in air to effective dose received by adults and 0.8 and 0.2 are the indoor and outdoor occupancy factors which is the fraction of time spent indoors and outdoors; respectively.

The worldwide range of the annual effective dose is $0.3-0.6 \mathrm{mSvwith}$ average of $0.48 \mathrm{mSv}$. For children and infants, the values are about $10 \%$ and $30 \%$ higher, due to increase in the value of the conversion coefficient from absorbed dose in air to effective dose [26].

\section{Excess life time cancer risk}

Excess lifetime cancer risk (ELCR) is defined as the excess probability of developing cancer cases during human lifetime due to exposure to values of AED and (ELCR) is calculated using Equation (10)[27].

\section{$\mathbf{E L C R}_{\text {tot }}=\mathrm{AEDE}_{\text {tot }} \mathbf{X} \mathbf{D}_{\mathrm{L}} \mathbf{X} \mathbf{R}_{\mathrm{F}}$}

Where: AED is the annual effective dose, $\mathrm{D}_{\mathrm{L}}$ is the duration of life (70 years) and $\mathrm{R}_{\mathrm{F}}$ is fatal cancer risk per $\mathrm{Sv}$. Its value is $\left(0.05 \mathrm{~Sv}^{-1}\right)$.

\section{RESULTS AND DISCUSSION}

\section{Radioactivity concentration}

\section{The levels in studied marbles}

The radioactivity concentration of $\left({ }^{226} \mathrm{Ra},{ }^{232} \mathrm{Th}\right.$, and $\left.{ }^{40} \mathrm{~K}\right)$ in studied marble types are listed in Table (2).

\begin{tabular}{|c|c|c|c|c|c|}
\hline Code & Type & Origin & ${ }^{226} \mathbf{R a}$ & ${ }^{232} \mathrm{Th}$ & ${ }^{40} K$ \\
\hline M1 & Crestya & Egypt & $59.82 \pm 0.15$ & $2.90 \pm 0.03$ & $5.97 \pm 0.05$ \\
\hline M2 & $\begin{array}{l}\text { White } \\
\text { Mesater }\end{array}$ & Egypt & $16.58 \pm 0.08$ & $2.92 \pm 0.03$ & $\leq 0.01$ \\
\hline M3 & Selvia & Egypt & $15.94 \pm 0.09$ & $5.27 \pm 0.05$ & $23.66 \pm 0.11$ \\
\hline M4 & Fleto & Egypt & $10.58 \pm 0.03$ & $3.26 \pm 0.02$ & $84.10 \pm 0.08$ \\
\hline M5 & Mall Brown & Egypt & $77.92 \pm 0.17$ & $0.54 \pm 0.01$ & $\leq 0.01$ \\
\hline M6 & Galala Daie & Egypt & $20.96 \pm 0.09$ & $\leq 0.5$ & $\leq 0.01$ \\
\hline M7 & Red Galala & Egypt & $14.83 \pm 0.03$ & $17.48 \pm 0.04$ & $61.83 \pm 0.07$ \\
\hline M8 & BresyaArora & Italy & $4.48 \pm 0.04$ & $\leq 0.50$ & $11.06 \pm 0.06$ \\
\hline M9 & Green Indian & India & $0.02 \pm 0.00$ & $0.86 \pm 0.02$ & $3.09 \pm 0.03$ \\
\hline M10 & White Turkey & Turkey & $64.17 \pm 0.15$ & $\leq 0.50$ & $4.17 \pm 0.04$ \\
\hline M11 & Emperador & Turkey & $22.56 \pm 0.09$ & $\leq 0.50$ & $11.90 \pm 0.07$ \\
\hline M12 & Red Eleganty & Chines & $41.72 \pm 0.12$ & $4.94 \pm 0.04$ & $26.99 \pm 0.10$ \\
\hline M13 & $\begin{array}{c}\text { Chocolate } \\
\text { Marble }\end{array}$ & Indian & $21.56 \pm 0.04$ & $22 . .^{24} \pm 0.04$ & $66.69 \pm 0.07$ \\
\hline M14 & Light Syrian & Syrian & $36.74 \pm 0.12$ & $\leq 0.50$ & $3.16 \pm 0.03$ \\
\hline M15 & White Cararta & Italy & $12.82 \pm 0.07$ & $2.13 \pm 0.03$ & $3.71 \pm 0.04$ \\
\hline M16 & Breshia & Italy & $15.64 \pm 0.09$ & $\leq 0.50$ & $12.36 \pm 0.08$ \\
\hline M17 & Travinto & Italy & $20.42 \pm 0.04$ & $7.51 \pm 0.02$ & $6.45 \pm 0.02$ \\
\hline
\end{tabular}

Table (2): The activity concentrations in studied marble $\left(\mathrm{BqKg}^{-1}\right)$

For ${ }^{226} \mathrm{Ra}$, the activity concentrations in the studied marble types are ranged from $0.02 \mathrm{BqKg}^{-1}$ to $77.92 \mathrm{BqKg}^{-1}$. The lowest value was found in M9 (Green Indian Marble) while the highest value was $\mathrm{f}$ in M5 (Egyptian Melly brown). The obtained average $\left(26.8 \mathrm{BqKg}^{-1}\right)$ is lower than the world average value $\left(32 \mathrm{BqKg}^{-1}\right)[24]$. The observed wide variation among the levels is mainly depends on the diversity of mineral and chemical compositions and geological formations of studied Marble types [5].

For ${ }^{232} \mathrm{Th}$, it is measured via its daughter $\left({ }^{228} \mathrm{Ac}\right)$ because they exist in secular equilibrium in solid dry environmental media. Its values were found to be ranged from less than $0.50 \mathrm{BqKg}^{-1}$ (MDA) to $22.24 \mathrm{BqK}^{-1}$ with an average value of $4.30 \mathrm{BqKg}^{-1}$. The lowest values recorded in types M6, M8, M10, M11, M14, and M16 on other hand the highest value found in type M13 (Egyptian 
Chocolate Marble).It is clear that, its average is lower than world average level $\left(45 \mathrm{~Bq} \mathrm{Kg}^{-1}\right)[24]$.

For ${ }^{40} \mathrm{~K}$, its values are ranged from less than $0.01 \mathrm{BqKg}^{-1}$ (MDA) and observed in type M2, M5, and M6 to $84.10 \mathrm{BqKg}^{-1}$ in type M4 (Fleto Marble) with an average value of $19.13 \mathrm{BqKg}^{1}$. All the recorded values were lower than the world average $412 \mathrm{BqKg}^{-1}$ [24].
The average values of radioactivity of ${ }^{226} \mathrm{Ra},{ }^{232} \mathrm{Th}$ and ${ }^{40} \mathrm{~K}$ in marble from different countries are presented in Table (3). It is clear that the values obtained in of the present study were within the recorded values in different countries, It is very important to point out that these values were not the representative values for the countries mentioned but for the regions from where the samples were collected $[16,19]$.

Table (3): Activity concentration of ${ }^{226} \mathrm{Ra},{ }^{232} \mathrm{Th}$ And ${ }^{40} \mathrm{~K}\left(\mathrm{BqKg}^{-1}\right)$ for marble in different Countries

\begin{tabular}{|c|c|c|c|c|c|}
\hline \multicolumn{4}{|c|}{$\begin{array}{l}\text { Average activity concentration } \\
\left(\mathrm{Bqkg}^{-1}\right)\end{array}$} & \multirow[t]{2}{*}{ Country } & \multirow[t]{2}{*}{ Reference } \\
\hline \multirow{2}{*}{ Min } & ${ }^{226} \mathrm{Ra}$ & ${ }^{232} \mathrm{Th}$ & ${ }^{40} \mathrm{~K}$ & & \\
\hline & 0.02 & 0.50 & 0.01 & \multirow{3}{*}{ Alexandria city, Egypt } & \multirow{3}{*}{ Present study } \\
\hline Max & 77.92 & 22.24 & 84.10 & & \\
\hline Average & 26.87 & 4.30 & 19.13 & & \\
\hline Min & 1.4 & 2.4 & 4.2 & \multirow{3}{*}{$\begin{array}{c}6^{\text {th }} \text { of October industrial } \\
\text { region, Egypt }\end{array}$} & \multirow{3}{*}{ Ebaid andBakr,2012[28] } \\
\hline Max & 54.2 & 87.7 & 1418.7 & & \\
\hline Average & 17.3 & 29.7 & 481.6 & & \\
\hline Min & 4 & 9 & 7 & \multirow{3}{*}{ Pakistan } & \multirow{3}{*}{ Muhammad,etal.,2000[29] } \\
\hline Max & 63 & 40 & 105 & & \\
\hline Average & 33 & 32 & 57 & & \\
\hline Min & 110 & 50 & 300 & \multirow{3}{*}{ Qena city, Upper Egypt. } & \multirow{3}{*}{ Ahmed N.K., 2005[30] } \\
\hline Max & 340 & 210 & 1500 & & \\
\hline Average & 205 & 115 & 865 & & \\
\hline Min & 1.76 & 4.12 & 418.07 & \multirow{3}{*}{ Pouma Cameroonian } & \multirow{3}{*}{ M. Ngachin et al.,2007[17] } \\
\hline Max & 2.2 & 5.63 & 451.63 & & \\
\hline Average & 2.01 & 5 & 430 & & \\
\hline Min & 6 & 12.2 & 79 & \multirow{3}{*}{ Ajloun, Jordan } & \multirow{3}{*}{ Ahmad and Hussein,1997[31] } \\
\hline Max & 17.19 & 28.3 & 1112 & & \\
\hline Average & 11.9 & 19.33 & 93.3 & & \\
\hline Min & 8.1 & 16.3 & 81.3 & \multirow{3}{*}{ Azraq, Jordan } & \multirow{3}{*}{ Ahmad and Hussein,1997[31] } \\
\hline Max & 15.8 & 23.4 & 88.9 & & \\
\hline Average & 20.1 & 11.4 & 85.9 & & \\
\hline Min & - & - & - & \multirow{3}{*}{ Algeria } & \multirow{3}{*}{ Amrani and Tahtat,2000[32] } \\
\hline Max & - & - & - & & \\
\hline Average & 23 & 18 & 310 & & \\
\hline
\end{tabular}




\section{The levels in studied granites}

The measured $\left({ }^{226} \mathrm{Ra},{ }^{232} \mathrm{Th}\right.$ and $\left.{ }^{40} \mathrm{~K}\right)$ in granite types are given in Table (4).It is clear that the levels of ${ }^{226}$ Raare ranged from $4.64 \mathrm{BqKg}^{-1}$ to $120.94 \mathrm{BqKg}^{-1}$ with an average of $42.90 \mathrm{~Bq} \mathrm{Kg}^{-1}$. The lowest was found in G4 (Double Black) while the highest observed in G3 (Baltic Brown).The deduced average value is higher than the world value $\left(32 \mathrm{BqKg}^{-1}\right)^{[22]}$. Additionally, about $50 \%$ of studied granites displayed values higher than the world average.

The ${ }^{232} \mathrm{Th}$ levels were ranged from $6.36 \mathrm{BqKg}^{-1}$ to 141.04 $\mathrm{BqKg}^{-1}$ with an average value of $58.400 \mathrm{BqKg}^{-1}$. The highest value found in type G5 (Pradisyo) while the lowest in type G8 (Forsan). Additionally, the average is higher than world average level $\left(45 \mathrm{BqKg}^{-1}\right)$ [24].

For ${ }^{40} \mathrm{~K}$, the concentration ranged from $99.41 \mathrm{BqKg}^{-1}$ in granite type $\mathrm{G} 1$ (Galaxy) to $1511.25 \mathrm{BqKg}^{-1}$ type $\mathrm{G} 3$ (Baltic Brown) with an average value of $933.36 \mathrm{BqKg}^{-1}$. Most of the examined granites displayed about $75 \%$ of the recorded values were higher than the world average.

This could be explained as potassium is a major element in the composition of feldspars (orthoclase, microcline biotite and muscovite and such minerals are present in main rock-forming granite. The potassium oxides content of K-feldspars are varied from 11 to $15 \%$, while in biotite from 8 to $10 \%$ and in muscovite from 10 to $11 \%$. It must be pointed that, such minerals are not common in basic of basaltic rocks [33].

Table (4): ${ }^{226} \mathrm{Ra},{ }^{232} \mathrm{Th}$ and ${ }^{40} \mathrm{Kactivity}$ concentrations $\left(\mathrm{BqKg}^{-1}\right)$ in studied granites

\begin{tabular}{|c|c|c|c|c|c|}
\hline Code & Type & Origin & ${ }^{226} \mathbf{R a}$ & ${ }^{232} \mathrm{Th}$ & ${ }^{40} \mathbf{K}$ \\
\hline G1 & Galaxy & India & $13.68 \pm 0.03$ & $10.24 \pm 0.03$ & $99.41 \pm 0.09$ \\
\hline G2 & Ablador & Brazil & $72.05 \pm 0.16$ & $65.88 \pm 0.16$ & $915.26 \pm 0.58$ \\
\hline G3 & Brown Baltic & Finland & $120.94 \pm 0.18$ & $131.90 \pm 0.19$ & $1511.25 \pm 0.65$ \\
\hline G4 & Double black & India & $4.64 \pm 0.04$ & $33.43 \pm 0.11$ & $280.98 \pm 0.32$ \\
\hline G5 & Pradisyo & India & $31.43 \pm 0.11$ & $141.04 \pm 0.23$ & $1307.24 \pm 0.70$ \\
\hline G6 & Red Aswan & Egypt & $18.90 \pm 0.08$ & $96.92 \pm 0.19$ & $1453.78 \pm 0.73$ \\
\hline G7 & Halayeb & Egypt & $6.89 \pm 0.05$ & $6.47 \pm 0.05$ & $236.94 \pm 0.30$ \\
\hline G8 & Forsan & Egypt & $94.74 \pm 0.19$ & $6.36 \pm 0.05$ & $955.03 \pm 0.59$ \\
\hline G9 & Kemic & Egypt & $40.93 \pm 0.12$ & $29.18 \pm 0.10$ & $1257.30 \pm 0.68$ \\
\hline G10 & Grey zelzal & Egypt & $29.77 \pm 0.11$ & $42.42 \pm 0.13$ & $744.00 \pm 0.52$ \\
\hline G11 & Gondola & Egypt & $15.62 \pm 0.08$ & $85.82 \pm 0.18$ & $1258.56 \pm 0.68$ \\
\hline G12 & Fardy & Egypt & $65.21 \pm 0.12$ & $51.13 \pm 0.11$ & $1180.62 \pm 0.51$ \\
\hline
\end{tabular}

The activity concentrations of ${ }^{226} \mathrm{Ra},{ }^{232} \mathrm{Th}$ and ${ }^{40} \mathrm{~K}$ in granite from different countries are listed in Table (5). $\mathrm{Ra}$, Th and $\mathrm{K}$ elements are not uniformly distributed among all rocks from which building materials are derived, that reflect the variabilities in its radioactivity [34]. This could be explained as during the melting and fractional crystallization of magma, which enables uranium and thorium to be concentrated in the liquid phase of silica-rich products.

Therefore, igneous rocks of granitic composition are strongly enriched in $\mathrm{U}$ and $\mathrm{Th}$. In such products the averages of uranium and thorium are $5 \mathrm{ppm}$ and $15 \mathrm{ppm}$ compared with rocks of basaltic or ultramafic composition[35].The rocky features of granites are frequently produce characteristic alterations in the relationship between the natural radionuclides $(\mathrm{Th}, \mathrm{U}, \mathrm{K}$, $\mathrm{Th} / \mathrm{U}$ and $\mathrm{Th} / \mathrm{K})[35,36]$.

Since radium and thorium are characterized by their longer half-lives, therefore, their daughters (radon and thoron gases or their gamma emitting radionuclides) generated in interior space and in building materials are considered to be constant during the lifetime of building.

Table (5): Activity concentration of ${ }^{226} \mathrm{Ra},{ }^{232} \mathrm{Th}$ and ${ }^{40} \mathrm{~K}$ (in $\mathrm{Bqkg}^{-1}$ ) for granite in different countries

\begin{tabular}{|c|c|c|c|c|c|c|}
\hline \multirow[t]{2}{*}{$\begin{array}{c}\text { Sample } \\
\text { type }\end{array}$} & \multicolumn{4}{|c|}{$\begin{array}{l}\text { Average activity concentration } \\
\qquad\left(\mathbf{B q k g}^{-1}\right)\end{array}$} & \multirow{2}{*}{ Country } & \multirow{2}{*}{ Reference } \\
\hline & \multirow{4}{*}{$\begin{array}{c}\text { Max } \\
\text { Average }\end{array}$} & ${ }^{226} \mathrm{Ra}$ & ${ }^{232} \mathrm{Th}$ & ${ }^{40} \mathrm{~K}$ & & \\
\hline \multirow{22}{*}{ 茕 } & & 4.64 & 6.36 & 99.41 & \multirow{3}{*}{$\begin{array}{l}\text { Alexandria } \\
\text { city, Egypt }\end{array}$} & \multirow{3}{*}{ Present study } \\
\hline & & 120.94 & 141.04 & 1511.25 & & \\
\hline & & 42.90 & 58.40 & 933.36 & & \\
\hline & Min & 5.8 & 0.3 & 303 & \multirow{3}{*}{$\begin{array}{c}\text { 6th of } \\
\text { October } \\
\text { industrial } \\
\text { region, } \\
\text { Egypt }\end{array}$} & \multirow{3}{*}{$\begin{array}{c}\text { Ebaid and } \\
\text { Bakr,2012 [28] }\end{array}$} \\
\hline & Max & 74 & 101 & 1958 & & \\
\hline & Average & 33 & 48 & 1128 & & \\
\hline & Min & 1.6 & 30 & 49 & \multirow{3}{*}{ Greek } & \multirow{3}{*}{$\begin{array}{l}\text { Pavlidou et } \\
\text { al,2006[33] }\end{array}$} \\
\hline & Max & 170 & 354 & 1592 & & \\
\hline & Average & 64 & 81 & 1104 & & \\
\hline & Min & 1 & 1 & 50 & \multirow{3}{*}{ Cyprus } & \multirow{3}{*}{ Tzortzis,2003 [7] } \\
\hline & Max & 906 & 588 & 1606 & & \\
\hline & Average & 143 & 77 & 1230 & & \\
\hline & \multirow{2}{*}{ Min } & ${ }^{226} \mathrm{Ra}$ & ${ }^{232} \mathrm{Th}$ & ${ }^{40} \mathrm{~K}$ & \multirow{4}{*}{ Greece } & \multirow{4}{*}{$\begin{array}{l}\text { Stoulos et } \\
\text { al.,2003[1] }\end{array}$} \\
\hline & & 2 & 1 & 50 & & \\
\hline & Max & 195 & 450 & 3800 & & \\
\hline & Average & 67 & 98 & 1200 & & \\
\hline & Min & 80 & 100 & 250 & \multirow{3}{*}{$\begin{array}{l}\text { Qena city, } \\
\text { Upper } \\
\text { Egypt }\end{array}$} & \multirow{3}{*}{$\begin{array}{l}\text { Ahmed N.K., } \\
2005[30]\end{array}$} \\
\hline & Max & 330 & 140 & 1300 & & \\
\hline & Average & 187 & 118 & 852 & & \\
\hline & Min & 165 & 71 & 1048 & \multirow{3}{*}{$\begin{array}{l}\text { Gatter II, } \\
\text { Egypt }\end{array}$} & \multirow{3}{*}{$\begin{array}{l}\text { El-Shershaby, } \\
\text { 2002[37] }\end{array}$} \\
\hline & Max & 27851 & 274 & 1230 & & \\
\hline & Average & 6017.9 & 113.2 & 1140.4 & & \\
\hline
\end{tabular}




\section{The levels in studied ceramics}

The radioactivity of $\left({ }^{226} \mathrm{Ra},{ }^{232} \mathrm{Th}\right.$ and $\left.{ }^{40} \mathrm{~K}\right)$ in several colors and grades of ceramic final products are given in Table (6).It is clear that ${ }^{226} \mathrm{Ra}$, the concentration ranged from $9.15 \mathrm{BqKg}^{-1}$ to $97.07 \mathrm{BqKg}^{-1}$, the lowest value was found in $\mathrm{C} 6$ while the highest value in $\mathrm{C} 10$. It is the average of ${ }^{226} \mathrm{Ra}\left(47.73 \mathrm{BqKg}^{-1}\right)$ exceeds the world average value $32 \mathrm{BqKg}^{-1[24]}$. Additionally, about $75 \%$ of the recorded values were higher than the world average.

For ${ }^{232} \mathrm{Th}$ the levels are ranged from $30.68 \mathrm{BqKg}^{-1}$ to $190.54 \mathrm{BqKg}^{-1}$ with an average of $66.09 \mathrm{BqKg}^{-1}$. The highest level found in type $\mathrm{C} 6$ while the lowest was recorded in type $\mathrm{C} 14$, the average level of ${ }^{232} \mathrm{Th}$ is higher than world average level $45 \mathrm{BqKg}^{-1}$ [24].

For ${ }^{40} \mathrm{~K}$, the concentration ranged from $209.56 \mathrm{BqKg}^{-1}$ in ceramic type $\mathrm{C} 4$ to $490.14 \mathrm{BqKg}^{-1}$ in ceramic type $\mathrm{C} 3$ with an average of $385.59 \mathrm{BqKg}^{-1}$. About $44 \%$ of the record levels exceeding the world average $412 \mathrm{~Bq} \mathrm{Kg}^{-1}$ [24].

Table (6): ${ }^{226} \mathrm{Ra},{ }^{232} \mathrm{Th}$ and ${ }^{40} \mathrm{~K}$ activity concentrations $\left(\mathrm{Bqkg}^{-1}\right)$ in studied ceramic types

\begin{tabular}{cccc}
\hline Code & ${ }^{226} \mathbf{R a}$ & ${ }^{232} \mathbf{T h}$ & ${ }^{40} \mathbf{K}$ \\
\hline C1 & $59.10 \pm 0.15$ & $40.02 \pm 0.12$ & $412.18 \pm 0.39$ \\
C2 & $25.44 \pm 0.10$ & $38.89 \pm 0.12$ & $275.74 \pm 0.32$ \\
C3 & $65.50 \pm 0.07$ & $76.33 \pm 0.08$ & $490.14 \pm 0.20$ \\
C4 & $57.42 \pm 0.15$ & $32.49 \pm 0.11$ & $209.56 \pm 0.28$ \\
C5 & $63.13 \pm 0.04$ & $159.00 \pm 0.06$ & $417.67 \pm 0.10$ \\
C6 & $9.15 \pm 0.06$ & $190.54 \pm 0.27$ & $392.47 \pm 0.38$ \\
C7 & $16.15 \pm 0.09$ & $46.34 \pm 0.16$ & $372.96 \pm 0.46$ \\
C8 & $46.38 \pm 0.16$ & $65.81 \pm 0.19$ & $328.89 \pm 0.43$ \\
C9 & $32.39 \pm 0.13$ & $43.17 \pm 0.15$ & $392.68 \pm 0.47$ \\
C10 & $97.07 \pm 0.23$ & $52.01 \pm 0.17$ & $484.58 \pm 0.52$ \\
C11 & $37.91 \pm 0.15$ & $53.79 \pm 0.17$ & $345.99 \pm 0.44$ \\
C12 & $89.91 \pm 0.22$ & $46.05 \pm 0.16$ & $419.07 \pm 0.48$ \\
C13 & $41.41 \pm 0.06$ & $87.48 \pm 0.08$ & $423.99 \pm 0.18$ \\
C14 & $54.44 \pm 0.17$ & $30.68 \pm 0.13$ & $343.56 \pm 0.44$ \\
C15 & $10.55 \pm 0.08$ & $56.43 \pm 0.18$ & $468.84 \pm 0.51$ \\
C16 & $57.76 \pm 0.18$ & $38.46 \pm 0.15$ & $391.10 \pm 0.47$ \\
\hline
\end{tabular}

In the ceramic industry one of the mean goals in the application of a glaze is to improve the aesthetic of the finished product. The reflectance color of ceramic glazes depends on the distribution of grain size and on the refraction index of both and vitreous phases and pigment[38-40].

These characteristics are mainly due to the raw materials from which it made. The most one of these materials is zircon $\left(\mathrm{ZrSiO}_{4}\right)$ due to its high refraction index (1.96) and is considerably less expensive than titanium dioxide. Also $\mathrm{ZrO}_{2}$ and $\mathrm{SiO}_{2}$ used as pacifier opacity and whiteness in ceramic glazes [41-43].

\section{The levels in ceramic raw materials}

The radioactivity were measured in the base materials used in ceramic manufacturing after crushing using a roller crushed and screening to as the fine powders used to the designed proportions. The observed radioactivity of $\left({ }^{226} \mathrm{Ra},{ }^{232} \mathrm{Th}\right.$ and $\left.{ }^{40} \mathrm{~K}\right)$ are shown in Table (7).

Table (7): ${ }^{226} \mathrm{Ra},{ }^{232} \mathrm{Th}$ and ${ }^{40} \mathrm{~K}$ activity concentrations $\left(\mathrm{Bqkg}^{-1}\right)$ in Ceramic raw materials

\begin{tabular}{ccccc}
\hline Sample ID & Name & ${ }^{226} \mathbf{R a}$ & ${ }^{232} \mathbf{T h}$ & ${ }^{40} \mathbf{K}$ \\
\hline CRM1 & Sand & $6.81 \pm 0.05$ & $5.93 \pm 0.05$ & $166.19 \pm 0.25$ \\
CRM2 & Feldspar & $70.98 \pm 0.16$ & $48.94 \pm 0.13$ & $1760.62 \pm 0.81$ \\
CRM3 & Tafla & $1.99 \pm 0.03$ & $70.41 \pm 0.20$ & $285.23 \pm 0.40$ \\
CRW4 & Zirconium & $16307.46 \pm 10.43$ & $1738.69 \pm 3.40$ & $532.95 \pm 1.88$ \\
\hline
\end{tabular}

For ${ }^{226} \mathbf{R a}$, the concentration ranges from $1.99 \mathrm{BqKg}^{-1}$ to $16307.46 \mathrm{BqKg}^{-1}$ with an average level of 4096.81 $\mathrm{BqKg}^{-1}$ the lowest value was in Tafla while the highest in zirconium. The ${ }^{232} \mathrm{Th}$ concentrations are ranged from $5.93 \mathrm{BqKg}^{-1}$ to $1738.69 \mathrm{BqKg}^{-1}$ with an average level of $465.99 \mathrm{BqKg}^{1}$. The highest one found in zirconium. For ${ }^{40} \mathrm{~K}$, the concentrations are ranged from 166.19 $\mathrm{BqKg}^{-1}$ in sand to $1760.62 \mathrm{BqKg}^{-1}$ in feldspar with an average value of $686.25 \mathrm{BqKg}^{-1}$. These results showed that, about $44 \%$ of the record levels were higher than the world average $\left(412 \mathrm{BqKg}^{-1}\right)$ [24].

\section{Radiological Risk Assessment for Study Samples}

The average values of $\mathrm{Ra}_{\mathrm{eq}}, \mathrm{H}_{\mathrm{ex}}, \mathrm{H}_{\mathrm{in}}, \mathrm{AED}$ and the excess lifetime cancer risk are listed in Table (8). Results of $\mathrm{Ra}_{\mathrm{eq}}$ for all studied materials revealed that Green Indian Marble displayed the lowest value $\left(1.48 \mathrm{Bqkg}^{-1}\right)$ while the highest observed in Baltic Brown granite (425.92 $\mathrm{Bqkg}^{-1}$ ). It is clear that, all values except (Baltic Brown granite) values are less than the maximum guidance value of $370 \mathrm{Bqkg}^{-1}$, that recommended by the Organization for Economic Cooperation and Development $[44,45]$.

The $\mathbf{H}_{\text {ex }}$ values revealed that (Green Indian) gives the minimum, on other hand, (Baltic Brown gives the highest level of (1.15) exceeding the guidance level 1. The $\mathbf{H}_{\text {in }}$ values revealed that Baltic Brown give value of (1.48) that is above unity which is the guidance level. The maximum level that observed in Baltic Brown is due to its higher activity concentrations of the three radionuclides $\left({ }^{232} \mathrm{Th},{ }^{226} \mathrm{Ra},{ }^{40} \mathrm{~K}\right)$. Therefore, Baltic Brown granite and their corresponding fractional contribution increased the internal and external radiation hazard indices. Therefore, Baltic Brown granite could pose a significant radiological hazard when used for different applications.

As shown in Table (8) it is clear that, all of the recorded absorbed dose rates in outdoor were below the world average $\left(55 \mathrm{nGyh}^{-1}\right)$, on the other hand, about 5\% 
of the absorbed dose rates in indoor were above the world average $\left(60 \mathrm{nGyh}^{-1}\right)$.Also $75 \%$ of the granite values in outdoor were above the world average, while indoor average was found to be $179.31 \mathrm{nGyh}^{-1}$ and is approximately 3 times the world average $\left(60 \mathrm{nGyh}^{-1}\right)$.

For marble samples, the annual effective dose (outdoor), was observed to be ranged from $0.87 \mu \mathrm{Svy}^{-1}$ to $41.64 \mu \mathrm{Svy}^{-1}$ with an average $18.72 \mu \mathrm{Svy}^{-1}$. While the annual effective dose (indoor) are ranged from 5.95 to $354.88 \mu \mathrm{Svy}^{-1}$ with an average of $152.18 \mu \mathrm{Svy}^{-1}$. It is clear that, the outdoor and indoor exposures to radiation originated from marble are lower than the annual worldwide-recommended effective dose for outdoor $\left(70 \mu \mathrm{Svy}^{-1}\right)$ and for indoor $\left(450 \mu \mathrm{Svy}^{-1}\right)$ [46].

The associated ELCR $_{\text {out }}$ levels are ranged from non detected risk to $0.16 \times 10^{-3}$ with an average of $0.07 \times 10^{-3}$. ELCR $_{\text {tot }}$ ranges from $0.03 \times 10^{-3}$ to $1.53 \times 10^{-3}$ with an average of $0.66 \times 10^{-3}$. It was observed that these values are lower than the worldwide recommended value except Mall Brown marble.

Table (8): Radiological risk parameters for studied marble, granite and ceramic.

\begin{tabular}{|c|c|c|c|c|c|}
\hline \multicolumn{3}{|c|}{ Radiological Assessment Parameters } & Marble & Granite & Ceramic \\
\hline \multirow{3}{*}{\multicolumn{2}{|c|}{$\begin{array}{c}\mathrm{Ra}_{\mathrm{eq}} \\
\mathbf{B q} / \mathbf{k g}\end{array}$}} & Min. & 1.484 & 34.39 & 102.28 \\
\hline & & Max. & 78.689 & 425.92 & 322.65 \\
\hline & & Av. & 34.485 & 198.28 & 171.93 \\
\hline \multirow{3}{*}{\multicolumn{2}{|c|}{$\mathbf{H}_{\mathrm{ex}}$}} & Min. & Non detected & 0.09 & 0.28 \\
\hline & & Max. & 0.21 & 1.15 & 0.87 \\
\hline & & Av. & 0.09 & 0.54 & 0.46 \\
\hline \multirow{3}{*}{\multicolumn{2}{|c|}{$\mathbf{H}_{\text {in }}$}} & Min. & Non detected & 0.11 & 0.34 \\
\hline & & Max. & 0.42 & 1.48 & 1.04 \\
\hline & & Av. & 0.17 & 0.65 & 0.59 \\
\hline \multirow{6}{*}{$\begin{array}{c}\text { Absorbed Dose } \\
\text { Rate }\end{array}$} & \multirow{3}{*}{$\underset{\mathrm{nGy} / \mathrm{h}}{\mathrm{D}_{\text {out }}}$} & Min. & 0.71 & 16.88 & 48.34 \\
\hline & & Max. & 33.86 & 203.31 & 150.45 \\
\hline & & Av. & 15.22 & 96.54 & 80.62 \\
\hline & \multirow{3}{*}{$\underset{n G y / h}{D_{\text {in }}}$} & Min. & 1.21 & 31.90 & 88.52 \\
\hline & & Max. & 72.28 & 378.77 & 266.81 \\
\hline & & Av. & 30.99 & 179.31 & 147.85 \\
\hline \multirow{9}{*}{$\begin{array}{c}\text { Annual Effective } \\
\text { Dose Equivalent } \\
\mu \mathrm{Sv} / \mathrm{y}\end{array}$} & \multirow{3}{*}{$\begin{array}{c}\mathbf{A E D}_{\text {out }} \\
\boldsymbol{\mu S \mathrm { Sv } / \mathrm { y }}\end{array}$} & Min. & 0.87 & 20.76 & 59.45 \\
\hline & & Max. & 41.64 & 250.07 & 185.05 \\
\hline & & Av. & 18.72 & 118.74 & 99.16 \\
\hline & \multirow{3}{*}{$\begin{array}{l}\mathrm{AED}_{\text {in }} \\
\mu \mathrm{Sv} / \mathbf{y}\end{array}$} & Min. & 5.95 & 156.64 & 434.63 \\
\hline & & Max. & 354.88 & 1859.74 & 1310.01 \\
\hline & & Av. & 152.18 & 880.41 & 725.93 \\
\hline & \multirow{3}{*}{$\begin{array}{l}\mathrm{AED}_{\text {tot }} \\
\mu \mathrm{S} v / \mathbf{y}\end{array}$} & Min. & 6.82 & 177.40 & 494.08 \\
\hline & & Max. & 396.53 & 2109.81 & 1495.06 \\
\hline & & Av. & 170.90 & 999.15 & 825.09 \\
\hline \multirow{9}{*}{$\begin{array}{c}\text { Excess Lifetime } \\
\text { Cancer Risk } \\
\left(10^{-3}\right)\end{array}$} & \multirow{3}{*}{$\begin{array}{c}\text { ELCR }_{\text {out }} \\
\left(10^{-3}\right)\end{array}$} & Min. & Non detected & 0.08 & 0.23 \\
\hline & & Max. & 0.16 & 0.96 & 0.71 \\
\hline & & Av. & 0.07 & 0.46 & 0.38 \\
\hline & \multirow{3}{*}{$\begin{array}{c}\mathbf{E L C R}_{\text {in }} \\
\left(10^{-3}\right)\end{array}$} & Min. & 0.02 & 0.60 & 1.90 \\
\hline & & Max. & 1.37 & 7.16 & 5.76 \\
\hline & & Av. & 0.59 & 3.39 & 3.18 \\
\hline & \multirow{3}{*}{$\begin{array}{c}\mathbf{E L C R}_{\text {tot }} \\
\left(10^{-3}\right)\end{array}$} & Min. & 0.03 & 0.68 & 1.90 \\
\hline & & Max. & 1.53 & 8.12 & 5.76 \\
\hline & & Av. & 0.66 & 3.85 & 3.18 \\
\hline
\end{tabular}

- $\quad$ Note: $\left(\mathrm{H}_{\mathrm{ex}}\right.$ and $\left.\mathrm{H}_{\mathrm{in}}\right)$ are hazard indices external and internal, indoor and outdoor air absorbed dose rate $\left(\mathrm{D}_{\text {in }}\right.$ and $\left.\mathrm{D}_{\text {out }}\right)$ are; $(\mathrm{AED}$ in ,AED out, $\left.\mathrm{AED}_{\text {tot }}\right)$ are indoor, outdoor and total annual effective dose ; $\left(\mathrm{ELCR}_{\text {in }}, \mathrm{ELCR}_{\text {out }}\right.$ and ELCR $\mathrm{tot}_{\text {) }}$ are indoor, outdoor and total excess lifetime cancer risk. 
For Granite, AED outdoor are ranged from $20.76 \mu \mathrm{Svy}^{-1}$ to $250.07 \mu \mathrm{Svy}^{-1}$ with an average of $118.74 \mu \mathrm{Sy}^{-1}$ which is above the world average $\left(70 \mu \mathrm{Svy}^{-1}\right)$ [46].AED indoor are ranged from $434.63 \mu \mathrm{Svy}^{-1}$ to $1310.01 \mu \mathrm{Svy}^{-1}$. It was found that, about $81 \%$ of the values are higher than the world average $\left(450 \mu \mathrm{Svy}^{-1}\right)[46]$.

ELCRout for granite varies from $0.08 \times 10^{-3}$ to $0.96 \times 10^{-3}$ with mean value of $0.46 \times 10^{-3}$ were higher than the worldwide recommended value $0.29 \times 10^{-3}$, while The ELCRtot varies from $0.68 \times 10^{-3}$ to $8.12 \times 10^{-3}$ with mean value of $3.85 \times 10^{-3}$ which is higher than the worldwide recommended value $1.45 \times 10^{-33}$.

For ceramic, the AED outdoor are ranged from $59.45 \mu \mathrm{Svy}^{-1}$ to $185.05 \mu \mathrm{Svy}^{-1}$ with an average $99.16 \mu \mathrm{Svy}^{-1}$ which is above the standard annual effective dose equivalent outdoor value is $70 \mu \mathrm{Svy}^{-1}[45,46]$.

Results revealed that, about $63 \%$ of records are higher than $70 \mu \mathrm{Svy}^{-1}$. The obtained AED indoor are observed to be ranged from $434.63 \mu \mathrm{Svy}^{-1}$ to $1310.01 \mu \mathrm{Svy}^{-1}$ with an average value $725.93 \mu \mathrm{Svy}^{-1}$.

For ceramic the deduced ELCR out $_{\text {varies from }}$ $0.23 \times 10^{-3}$ to $0.71 \times 10^{-3}$ with average of $0.38 \times 10^{3}$ which is higher than the worldwide recommended value

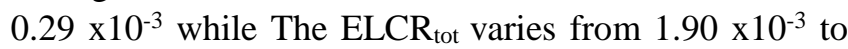
$5.76 \times 10^{-3}$ with mean value of $3.18 \times 10^{-3}$ which higher than the worldwide recommended value $1.45 \times 10^{-3}$.

Although the ELCR reported herein are all higher than the world average, the chances of increasing the risks of cancer in a life time are still negligible even the indoor ELCR.

\section{CONCLUSIONS}

From this study, the following conclusions can be drawn:

- Regarding the radioactivity content, the values showed that green Indian marble and Galaxy granite are more suitable for application in urban and general civil constructions.

- Regarding to radium equivalent, all studied marble, granite, and ceramic, the observed values were lower than the guidance level $370 \mathrm{Bqkg}^{-1}$ except Baltic Brown granite type which displayed radiation Hazard Indices (External and Internal) exceeding the unity.

- For marble, the annual effective doses are lower than the worldwide for both outdoor and indoor exposers except Mall Brown type.

- Granites results indicated that in the case of indoor exposures about $81 \%$ of the values are higher than the world average although, of this, the levels of risk indicators would not pose a significant radiological risk when used as ornamental features for different applications except Baltic Brown granite. However, it is recommended to reduce granite utilization for indoor of small ventilated spaces.

- Zircon gives the highest levels for ${ }^{232} \mathrm{Th}$ and ${ }^{226} \mathrm{Ra}$ among the other raw materials of ceramic manufacturing; therefore, amount of zircon adding should be regulated to be radiologically within save level.

\section{REFERENCES}

[1] Stoulos S., Manolopoulou M., Papastefanou C. (2003). Assessment of natural radiation exposure and radon exhalation from building materials in Greece. Journal of Environmental Radioactivity 69 225-240.

[2] IAEA, (1987) Preparation and Certification of Gamma Spectrometry Reference Materials, RGU-1, RGTH-1 and RGK-1, International Atomic Energy Agency, Report /RL/148.

[3] Wedepohl, K.H., (1995) .The composition of the continental crust. Geochimica et CosmochimicaActa, 59 pp1217-1232.

[4] Zong-Xian Zhang (2016). Rock Fracture and Blasting Theory and Applications. Pages 69-88

https://doi.org/10.1016/B978-0-12-8026885.00003-8

[5] Fares S., Ali. A. M., Yassene A., Ashour M. K., Abu-Assy M., and Abd El-Rahman (2011). Natural radioactivity and the resulting radiation doses in some kinds ofcommercially marble collected from different quarries and factories in Egypt. Natural Science Vol.3, No.10, DOI10.4216/ns.

[6] Abbasi A. and Mirekhtiary F. (2011) Survey Gamma Radiation Measurements in commercially used Natural Tiling Rocks in Iran. World Academy of Science, Engineering and Technology International Journal of Mathematical, Computational, Physical, Electrical and Computer Engineering Vol:5, No:4.

[7] MichalisTzortzis, HaralabosTsertos, Stelios Christofides and George Christodoulides, (2003). Gamma radiation measurements and dose rates in commercially-used natural tiling rocks (granites). Journal of Environmental Radioactivity 70 pp.223235 . 
[8] Snelling A., and Wood morappe, J., (1998). Rapid Rocks Granites. Creation Ex Nihilo 21(1), 37-39.

[9] El-Fadaly E., Bakr I. M., and Abo Breka M. R., (2010) .Recycling of ceramic industry wastes in floor tiles recipes. Journal of American Science, 6 (10) pp. 241- 247.

[10] Mohamed M. EL-Sayed Seleman, Neven Ali, Magdy S. Basta, and Farouk A. Mohamed. (2011). Assessment of Using a New Egyptian Fluxing Material for Ceramic Tiles Production. JPME, 14 (2), (PP.67-89).

[11] Saleh I. H., Othman I. M., Ghatass Z.F., andMetwally M.A. (2018). Radiological Risk Assessment in a Type of Complex Petroleum Refinery in Egypt. Arab Journal of Nuclear Sciences and Applications Vol. 51, 4, 31-43 (2018).

[12] Saleh I.H., Abdel-Halim A.A. (2018).Cosmogenic beryllium-7 in soil, rainwater and selected plant species to evaluate the vegetal interception of atmospheric fine particulate matter.ISOTOPES IN ENVIRONMENTAL AND HEALTH STUDIES, 54(4): (2018) 392-402, production and hosting by Taylor and Francis

[13] Saleh I.H. (2017) Depleted uranium residues, NORMs and $137 \mathrm{Cs}$ in the coastal zone soilof Musandam Peninsula, Hurmuz strait region, Sultanate of Oman.Journal of Radiation Research and Applied Sciences,Elsevier, ScienceDirect, 2017.

[14] El-Afifi, E.M., Awwad, N.S. Characterization of the TE-NORM waste associated with oil and natural gas production in Abu Rudeis, Egypt. J. Environ. Rad., 82, 7-19 (2005).

[15] Saleh I.H, Abdel-Halim A.A. (2017). 7Be in soil, deposited dust and atmospheric air and its using to infer soil erosion along Alexandria region, Egypt .Journal of Environmental Radioactivity 172 pp. 24-29, Elsevier.

[16] Beretaka, J., Mathew, P.J., 1985. Natural radioactivity of Australian building materials, industrial wastes and by products. Health Physics 48, pp87-95.

[17] Ngachin M., Garavaglia M., Giovani C. and Kwato Njock M.G., and Nourreddine A. (2007). Assessment of natural radioactivity and associated radiation hazards in some Cameroonian building materials. Radiation Measurements 42 pp. $61-67$.
[18] Guan K.N., Yu X.J., Stoks M.J. and Young, E.C. (1992). The assessment of natural radiation dose committed to the Hong Kong people. Journal of Environmental Radioactivity, 17, 931.

[19] Hayumbu, P., Zaman, M. B., Lubaba, N. C. H., \&Munsanje, S. S. (1995). Natural radioactivity in Zambian building materials collected from Lusaka. Journal of Radioanalytical and Nuclear Chemistry, 199(3), 229.

[20] El-Hussein A. (2005) .A study on natural radiation exposure in different realistic living rooms. Journal of Environmental Radioactivity ,79. pp.355-367.

[21] OECD (1979). Organization of Economic Cooperation and Development, Exposure to Radiation from Natural Radio- activity in Building Materials., Report by a Group of Experts of the OECD Nuclear Energy Agency, OECD, Paris.

[22] Nada A. (2004). Gamma Spectroscopic Analysis for Estimation of Natural Radioactivity Levels in Some Granite Rocks of Eastern Desert, Egypt, Cairo Arab Journal of Nuclear Science and Application, Vol. 37, No. 2, pp. 201- 222.

[23] UNSCEAR (2013). Sources, effects and risks of ionizing radiation: United Nations Scientific Committee on The Effects of Atomic Radiation: report to the general assembly with scientific annexes. Volumes II, scientific annex B. United Nations, New York.

[24] UNSCEAR (2008), Sources and effects of ionizing radiation, United Nations Scientific Committee on the Effects of Atomic Radiation, Volumes I, scientific annex A,B. United Nations, New York. ISBN 978-92-1-142274-0.

[25] UNSCEAR (1993). United Nations Scientific Committee on the Effects of Atomic Radiation Sources, effects and risks of ionizing radiation. Volumes I, scientific annex A, B, D. United Nations, New York.

[26] EL-Taher A and AL-Zahrani J H, (2014). Radioactivity measurement and radiation dose assessments in soil of Al-Qassim region, Saudi Arabia .Indian journal of pure and applied physics, Vol.52, and pp.147-154.

[27] Taskin, H., Karavus, M., Ay, P., Topuzoglu, A., Hindiroglu, S. and Karahan, G. (2009). Radionuclide concentrations in soil and lifetime cancer risk due to the gamma radioactivity in Kirklareli, Turkey. Journal 
of Environmental Radioactivity, 100, 49-53. doi:10.1016/j.jenvrad.2008.10.012.

[28] Ebaid Y. Y. and Bakr W. F., (2012). Investigating the Effect of Using Granite and Marble as A Building Material on The Radiation Exposure of Humans. Radiation Protection Dosimetry Advance Access published April 11, 2012. Radiation Protection Dosimetry, pp. 1-8.

[29] Muhammad Iqbal, Muhammad Tufail and Sikander M. Mirza. (2000) Measurement of natural radioactivity in marble found in Pakistan using a NaI (Tl) gamma-ray spectrometer. Journal of Environmental Radioactivity 51, pp. 255-265.

[30] Nour Khalifa Ahmed. (2005). Measurement of natural radioactivity in building materials in Qena city, Upper Egypt. Journal of Environmental Radioactivity ,83 pp.91-99.

[31] Ahmad, M.N., Hussein, A.J.A., (1997). Natural radioactivity in Jordanian Building materials and the associated radiation hazards. J. Environ. Radioact. 39, pp.9-22.

[32] Amrania D. and Tahtat M. (2000). Natural radioactivity in Algerian building materials. Applied Radiation and Isotopes 54 pp.687-689.

[33] Pavlidou S., Koroneos A, Papastefanou C., Christofides G. , Stoulos S., Vavelides M. (2006). Natural radioactivity of granites used as building materials. Journal of Environmental Radioactivity 89 pp.48-60.

[34] Slunga, E., (1988). Radon classification of building ground. Radiat. Prot. Dosim. 24 (114), PP.39-42.

[35] Rudnick RL and Gao S, (2003) .Composion of the continental crust. Treatise on Geochemistry vol. 3. Elsevier Amsterdam pp. 1-64.

[36] Keser R., KorkmazGörür F., Alp İ., and Okumuşoğlu N.T. (2013). Determination of radioactivity levels and hazards of sediment and rock samples in İkizdere and Kaptanpaşa Valley, Turkey. International Journal of Radiation Research, July 2013 Volume 11, No 3.

[37] El-Shershaby A. (2002). Study of radioactivity levels in granite of Gable Gattar II in the north eastern desert of Egypt. Applied Radiation and Isotopes 57 pp. 131-135.

[38] Schabbach L.M., Bondioli F., Fredel M.C. (2011). Colouring of opaque ceramic glaze with zircon pigments: Formulation with simplified KubelkaMunk model. Journal of the European Ceramic Society 31, pp.659-664.

[39] Blonski RP. The effect of zircon dissolution on the color stability of glazes. Ceram EngSciProc; 15(1):pp.249-65.

[40] Cer I.S. Colore (2003). Pigmented Coloration in Ceramic. Editor S.A.L.A srl, Modena, Italia.

[41] Earl DA, Clark DE, (2000). Effects of glazes frit oxides on crystallization and zircon pigment dissolution in white ware coatings. J Am Ceram Soc; 83 (9):pp2170-2176.

[42] Schabbach LM, Bondioli F, Ferrari AM, Manfredini T, Petter CO. and Fredel MC, (2007). Influence of firing temperature on the color developed by a (Zr, V) SiO4Pigmented opaque ceramic glaze. J Eur Ceram Soc; 27:1pp.79-84.

[43] Schabbach LM, Bondioli F, Ferrari AM, Manfredini T, Petter CO. and Fredel MC, (2008).Color in ceramic glazes: analysis of pigment and opacifier grain size distribution effect by spectrophotometer. J Eur Ceram Soc; 28:17pp.7781.

[44] UNSCEAR (1988). Report: Sources and effects of ionizing radiation. New York, NY, United Nation Scientific Committee on the Effects of Atomic radiation. Vol. I

[45] OECD, (1979). Organization of Economic Cooperation and Development, Exposure to Radiation from Natural Radio- activity in Building Materials., Report by a Group of Experts of the OECD Nuclear Energy Agency, OECD, Paris.

[46] UNSCEAR, (2000). (United Nations Scientific Committee on the Effects of Atomic Radiation), Report to the General Assembly, Volumes I, scientific annex A, B,C. United Nations, New York. 